\title{
Content of Iodine in Broiler Meat
}

\author{
I. HERZIG ${ }^{1}$, J. TRÁVNIČEK ${ }^{2}$, V. KURSA ${ }^{2}$, J. KROUPOVÁ ${ }^{2}$ I. ŘEZNÍČEK ${ }^{3}$ \\ ${ }^{1)}$ Veterinary Research Institute, Brno, Czech Republic \\ ${ }^{2}$ University of South Bohemia, Faculty of Agriculture, České Budějovice, Czech Republic \\ ${ }^{3)}$ Centre of Animal Hygiene, Kostelec u Jihlavy, Czech Republic
}

Received May 25, 2006

Accepted September 5, 2006

\begin{abstract}
Herzig I., J. Trávniček, V. Kursa, J. Kroupová, I. Řezníček: Content of Iodine in Broiler Meat. Acta Vet Brno 2007, 76: 137-141.

The present study brings current information on providing broilers with the required iodine level by the determination of its content in breast and leg muscles and on the relationship between those concentrations and iodine intake by the human population. The iodine content was assessed by the Sandell-Kolthoff method in 84 samples of broiler breast and leg muscles from seven farms in four districts of the Czech Republic, collected during the period from August to September 2004. Average iodine content in broiler breast and leg muscles was $18.9 \pm 6.71 \mu \mathrm{g} \mathrm{I} \cdot \mathrm{kg}^{-1}$ and $38.1 \pm 19.79$ $\mu \mathrm{g} \mathrm{I} \cdot \mathrm{kg}^{-1}$, respectively, and coefficient of variation was $35.5 \%$ and $52.0 \%$, respectively. Iodine concentration in leg muscles was statistically significantly higher $(P<0.0001)$ relative to breast muscles. Iodine level variations in the samples from respective farms were expressed in the levels range of 11.4 to $24.3 \mu \mathrm{g} \mathrm{I} \cdot \mathrm{kg}^{-1}$ and 18.3 to $61.2 \mu \mathrm{g} \mathrm{I} \cdot \mathrm{kg}^{-1}$ in breast and leg muscles, respectively. The detected variations might have been caused by different iodine saturation of broilers from different herds, manifestation of physiological ability of respective animals to utilize the iodine source, potential effect of goitrogens and environmental conditions. Statistical significance of correlation $(P<0.05)$ between average iodine levels in breast and leg muscles was confirmed in respective flocks $(\mathrm{r}=0.91)$. It is necessary to accept the iodine content in broiler meat in the balance of iodine supply in the shopping basket of consumers. Provided that the average annual consumption of poultry meat is $23.9 \mathrm{~kg}$ with the iodine content of $18.9 \mu \mathrm{g} \cdot \mathrm{kg}^{-1}$ and $38.1 \mu \mathrm{g} \cdot \mathrm{kg}^{-1}$ in breast and leg muscles, respectively, the annual iodine intake is 452 to $911 \mu \mathrm{g}$; that represents 0.8 to $1.7 \%$ of the requirement per year, which is $150 \mu \mathrm{g} \cdot \mathrm{day}^{-1}$ for an adult person.
\end{abstract}

Iodine levels, breast and leg muscles, iodine requirement, shopping basket

Over the past two decades, particular attention was concentrated on the iodine supplementation of the inhabitants of the Czech Republic. The initiative of human endocrinologists and hygienists to investigate the possibilities of how to increase the low iodine content in milk, meat and eggs and thus to extend the function and participation of food of animal origin in the prevention of iodine deficiency in humans was respected by veterinary and agricultural researchers ( Kaufmann et al. 1998ab). This group of foodstuffs are especially significant and non-substitutable under the conditions of our republic, with respect to their consumption and feeding behaviour of the consumers (Borkovcová and Řehůřková 2001).

The iodine content in products of animal origin correlated with the levels of animal supplementation with this trace element. Berg et al. (1988) and Maas et al. (1989) expressed correlation between iodine content in the diet and milk by the correlation coefficient $r=0.66$. The same data is related to the results of the experiments testing efficiency of iodine supplementation of feed rations (Berg et al. 1988; Anke et al. 1994; Herzig et al. 1999).

Approximately $80 \%$ of iodine in the mammalian body is present in thyroid gland; a certain proportion of ingested iodine is accumulated in soft tissues, above all in muscles and liver (Downer et al. 1981). Iodine supplementation of mixed feeds aimed at prevention of goiter

Address for correspondence:

Doc. MVDr. Ivan Herzig, CSc.

Veterinary Research Institute

Hudcova 70, 62132 Brno

Czech Republic

Phone +420 533331614

E-mail: herzig@vri.cz

http://www.vfu.cz/acta-vet/actavet.htm 
in humans (Anke et al. 1989) resulted in a triplicate milk iodine content and duplicate meat and hence meat product iodine content.

In association with the evaluation of a ten-year-period of complex prophylaxis of iodine deficiency in the Czech Republic, we monitored the situation in food animal-derived products.

The purpose of the present study was to survey iodine content in broiler chicken muscles before their processing in the food industry and thus to update information concerning optimum iodine intake by human population.

\section{Materials and Methods}

Iodine levels were determined in 84 samples of broiler (hybrid ROSS 308) breast and leg muscles from seven farms in four districts of the Czech Republic. The samples were collected after meat inspection at a chicken slaughterhouse in a meat-processing plant in K. during the period from August 2004 to September 2004. Six samples of muscles were collected from each selected farm. After obtaining samples, the researchers registered them in such a way so that the extramural anonymity of their origin may be observed, and they were kept frozen before analysis.

The iodine concentration of the muscle samples were assessed by spectrophotometric method using alkaline incineration based on the Sandell-Kolthoff reaction (Bed nář et al. 1964). The principle of the assessment is reduction of $\mathrm{Ce}^{4+}$ to $\mathrm{Ce}^{3+}$ in the presence of $\mathrm{As}^{3+}$ and catalytic effect of iodine. Mineralization is performed in a dry way in alkaline environment at $600^{\circ} \mathrm{C}$. By that method, the total iodine is assessed, i.e. both inorganic and protein-bound iodine.

The results obtained were evaluated by standard statistical methods. Average values (x), standard deviation $( \pm \mathrm{SD})$, variation coefficient $(\mathrm{V})$, median, correlation coefficient $(\mathrm{r})$ and statistical significance using the Tukey test were calculated (Motulsky 1999).

\section{Results}

The average iodine concentration in broiler breast and leg muscles was $18.9 \pm 6.71 \mu \mathrm{g} \mathrm{I} \cdot \mathrm{kg}^{-1}$ and $38.1 \pm 19.79 \mu \mathrm{g} \mathrm{I} \cdot \mathrm{kg}^{-1}$ fresh matter, respectively, and coefficient of variation was $35.5 \%$ and $52.0 \%$, respectively. Iodine concentration in leg muscles was statistically significantly higher $(P<0.0001)$ relative to breast muscles. Iodine level variations in samples from respective farms was expressed by the variation ranges of 11.4 to $24.3 \mu \mathrm{g} \mathrm{I} \cdot \mathrm{kg}^{-1}$ and 18.3 to $61.2 \mu \mathrm{g} \mathrm{I} \cdot \mathrm{kg}^{-}$ 1 in breast and leg muscles, respectively (Table 1 and 2, Fig. 1 and 2). Correlations of iodine content in breast and leg muscles $(r=0.91)$ were statistically significant $(P<0.05)$. Chicken meat iodine content was calculated as an average from the values of breast and leg muscles and was $28.5 \pm 14.84 \mu \mathrm{g} \mathrm{I} \cdot \mathrm{kg}^{-1}$.

Provided that the average annual consumption was $23.9 \mathrm{~kg}$ of poultry meat (Roubalová 2005 ) with the iodine content in breast and leg muscles of $18.9 \mu \mathrm{g} \cdot \mathrm{kg}^{-1}$ and $38.1 \mu \mathrm{g} \cdot \mathrm{kg}^{-1}$, the annual iodine intake is 452 to $911 \mu \mathrm{g}$, which represents 0.8 to $1.7 \%$ of the requirement per year; that is $150 \mu$ g.day ${ }^{-1}$ for an adult man (Delange 1993).

Table 1. Iodine content in breast and leg muscles $\left(\mu \mathrm{g} \mathrm{I} \cdot \mathrm{kg}^{-1}\right)$

\begin{tabular}{|c|c|c|c|c|c|c|c|c|}
\hline District & Farm & $\mathrm{n}$ & $\begin{array}{c}\text { Average live } \\
\text { weight }(\mathrm{kg})\end{array}$ & $\begin{array}{c}\text { Average } \\
\text { weight } \\
\text { of meat }(\mathrm{kg})\end{array}$ & $\begin{array}{c}\text { Iodine breast } \\
\text { muscles } \\
\mathrm{x} \pm \mathrm{SD}\end{array}$ & $\mathrm{V} \%$ & $\begin{array}{c}\text { Iodine leg } \\
\text { muscles } \\
\mathrm{x} \pm \mathrm{SD}\end{array}$ & $\mathrm{V} \%$ \\
\hline $\mathrm{Zn}$ & $\mathrm{KR}$ & 6 & 2.35 & 1.6 & $24.14 .13^{\mathrm{A}}$ & 17.1 & $61.219 .73^{* * \mathrm{~A}}$ & 32.2 \\
\hline $\mathrm{Tr}$ & $\mathrm{TR}$ & 6 & 2.5 & 1.5 & $24.33 .50^{\mathrm{A}}$ & 14.4 & $54.926 .10^{* \mathrm{AA}}$ & 47.5 \\
\hline $\mathrm{Zn}$ & $\mathrm{ST}$ & 6 & 1.9 & 1.3 & 17.26 .48 & 37.7 & $28.78 .14^{* \mathrm{bB}}$ & 28.4 \\
\hline $\mathrm{Zn}$ & $\mathrm{VA}$ & 6 & 2.45 & 1.5 & $11.46 .50^{\mathrm{B}}$ & 57.1 & $18.311 .28^{\mathrm{B}}$ & 61.6 \\
\hline $\mathrm{HK}$ & $\mathrm{PR}$ & 6 & 2.0 & 1.5 & 18.95 .94 & 31.4 & $25.68 .96^{\mathrm{B}}$ & 35.0 \\
\hline $\mathrm{Z}$ & $\mathrm{HR}$ & 6 & 2.0 & 1.5 & 17.66 .91 & 39.3 & $37.48 .61^{* *}$ & 23.0 \\
\hline $\mathrm{J}$ & $\mathrm{BA}$ & 6 & 2.35 & 1.45 & 18.75 .60 & 29.9 & $40.36 .87^{* *}$ & 17.0 \\
\hline Average & & & & & 18.96 .71 & 35.5 & 38.119 .79 & 52.0 \\
\hline
\end{tabular}

* $P<0.05 ; * * P<0.01$ statistical significance of differences between breast and leg muscles

$\mathrm{a}, \mathrm{b}$ statistical significance of differences among respective flocks $(P<0.05)$

A, B statistical significance of differences among respective flocks $(P<0.01)$ 


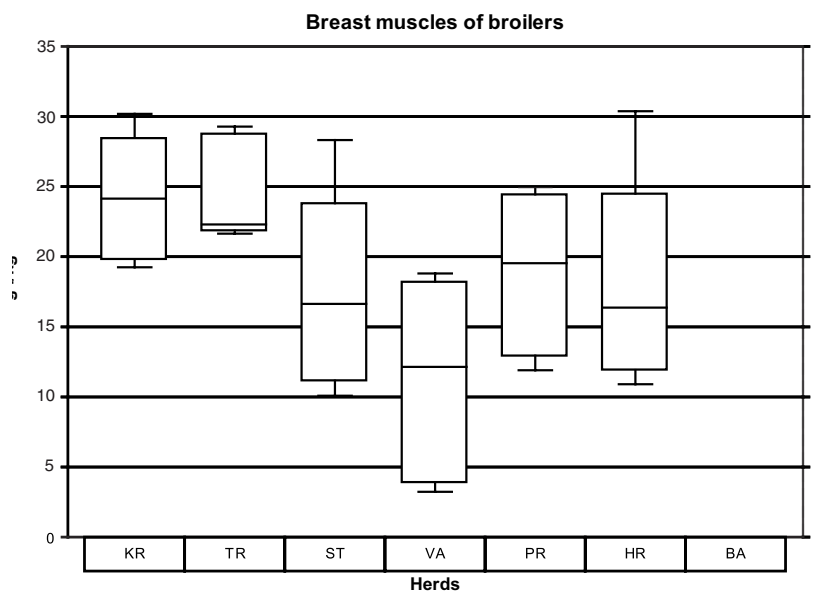

Fig. 1. Iodine content in breast muscles of broilers from the respective flocks, characterized by minimum and maximum values, median and 25 and 75 percentiles

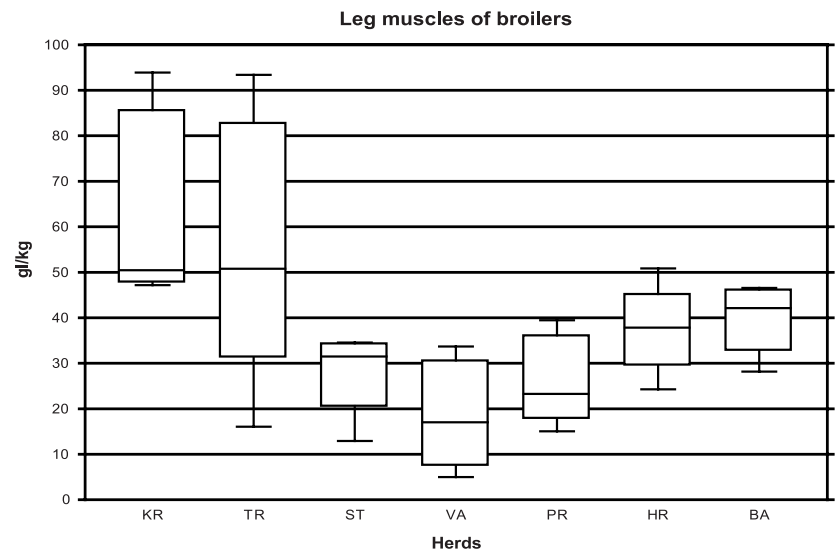

Fig. 2. Iodine content in leg muscles of broilers from the respective flocks, characterized by minimum and maximum values, median and 25 and 75 percentiles

\section{Discussion}

It is well known that fodder and concentrated feeds produced in the Czech Republic contain very low levels of iodine that is given by the geographic localization. It has been concluded that total iodine content in the diets is primarily affected by the quality of mineral supplements. Scientific information, qualified impulses, wide offer of mineral feed supplements containing iodine and the interest of the farmers resulted in the process of general iodine supplementation in the mid-1990s.

Total iodine content in the diets for food animals is particularly affected by the quality of synthetic supplements. Easily controllable iodine intake by the animals and iodine content in food of animal origin by the additives was experimentally demonstrated (Anke et al. 1989; Pennington 1990; Convey et al. 1977; Herzig et al. 1999). The use of iodine additives reflects both in optimization of thyroid gland function and iodine deposition in the internal organs, musculature and its secretion through milk. These also demonstrated that 
the problem of iodine deficient diets derived from the above mentioned constant conditions is unsolvable without compulsory iodine supplementation.

Based on the well-known fact that iodine content in meat is associated with the level of iodine supplementation of animals, the detected variability of findings indicates differences in iodine supplementation of broiler chickens in the Czech Republic. Despite the fact that the sampling places were chosen at random and numbers of examinations were relatively limited by the extent of financial subventions and capacity of the laboratory, we can consider our results as representative.

A higher iodine content in leg muscles may be explained by a higher level of their blood supply. Subsequently, higher iodine content resulting from deiodination of thyroid gland hormones in their target peripheral tissues is detected (Němečková 1991). In case the iodine supplementation is higher, it accumulates in soft tissues, above all in muscles and liver (Downer et al. 1981).

Some farmers still underestimate the significance and implications of these measures. Primarily, the attention is not paid to other, less recognised consequences of iodine deficiency such as reproductive dysfunctions, with reduced subsequent efficiency without diagnosed causes.

However, in any case, it is necessary that the farmers primarily accept the presented findings. It is particularly topical to control supplementation of feed rations with the iodine containing additives according to the physiological requirements and production conditions. It seems to be suitable to keep at systematic general monitoring of iodine content in foodstuffs of animal origin with the possibility of feedback to the agribusiness (Kursa et al. 2005).

\section{Obsah jodu v mase brojlerových kuřat}

Práce přináší aktuální poznatky o zajištění potřeby jodu u brojlerových kuřat posouzením jeho hladiny v prsní a stehenní svalovině a o vztahu těchto koncentrací k př́ijmu jodu lidskou populací. Metodou Sandell-Kolthoffa jsme stanovili koncentraci jodu v 84 vzorcích prsní a stehenní svaloviny brojlerových kuřat, získané ze sedmi chovů čtyř okresů ČR, v období srpen - září 2004. Průměrná koncentrace jodu byla ve svalovině prsní $18,9 \pm 6,71 \mu \mathrm{g} \mathrm{I} \cdot \mathrm{kg}^{-1}$, variační koeficient 35,5\%, ve svalovině stehenní $38,1 \pm 19,79 \mu \mathrm{g} \mathrm{I} \cdot \mathrm{kg}^{-1}$, variační koeficient $52,0 \%$. Koncentrace nalezené ve svalovině stehenní byly statisticky vysoce významně vyšší oproti svalovině prsní $(P<0,0001)$. Kolísání koncentrací jodu u vzorků z jednotlivých farem je vyjádřené variačním rozpětím 11,4 až $24,3 \mu \mathrm{g} \mathrm{I} \cdot \mathrm{kg}^{-1} \mathrm{u}$ svaloviny prsní a 18,3 až 61,2 $\mu \mathrm{g}$ $\mathrm{I} \cdot \mathrm{kg}^{-1} \mathrm{u}$ svaloviny stehenní. Zjištěné výkyvy lze považovat za odraz rozdílů $\mathrm{v}$ saturaci fyziologické potřeby brojlerů jodem, individuální schopnosti zvířat zdroj využít, možného působení strumigenních látek a environmentálních podmínek. Byla potvrzena statistická významnost korelace $(P<0,05)$ mezi průměrnými hodnotami jodu ve svalovině prsní a stehenní v jednotlivých chovech $(\mathrm{r}=0,91)$.

Obsah jodu v mase brojlerových kuřat je důležité akceptovat v bilancích př́ijmu jodu v potravním koši spotřebitelů. Při roční spotřebě $23,9 \mathrm{~kg}$ drůbežího masa, s obsahem jodu ve svalovině prsní $18,9 \mu \mathrm{g} \cdot \mathrm{kg}^{-1}$ a $38,1 \mu \mathrm{g} \cdot \mathrm{kg}^{-1}$ ve svalovině stehenní to představuje roční přísun 452 až $911 \mu \mathrm{g}$ jodu a zajištění 0,8 až $1,7 \%$ roční potřeby člověka, která je pro dospělého člověka udávána $150 \mu \mathrm{g} \cdot \mathrm{den}^{-1}$.

\section{Acknowledgements}

Supported by the Ministry of Agriculture of the Czech Republic (Grants No. MZe 1B44013 and No. MZe 000271 6201)

\section{References}

ANKE M, GROPPEL B, SCHOLZ M, HENNIG U 1994: Die Bedeutung des Jodgehaltes der Milch, Molkereierzeugnisse und des Fleisches für die Jodversorgung des Menschen in der Deutschland. Rekasan J. 1: 19-20 
ANKE M, WENK G, HEINRICH H, GROPPEL B, BAUCH K 1989: Die Wirkung jodierter Mineralstoffmischungen für Rind und Schwein auf die Jodversorgung und Strumaprophylaxe. Z Ges Inn Med 44: 41-44

BEDNÁŘ J, RÖHLING S, VOHNOUT S 1964: Determination of protein iodine content in blood serum (in Czech). Ceskoslov Farm 13: 203-209

BERG JN, PADGITT D, MCCARTHY B 1988: Iodine Concentration in Milk of Dairy Cattle Fed Various Amounts of Iodine as Ethylenediamine Dihydroiodide. J Dairy Sci 71: 3283-3291

BORKOVCOVÁ I, ŘEHU゚RKKOVÁ I 2001: Study of iodine exposure sources in foodstuffs (in Czech). Report of the National Institute of Public Health, Prague 6: 5-80

CONVEY EM, CHAPIN LT, KESNER JS, HILLMAN D, CURTIS AR 1977: Serum thyrotropin and thyroxin after thyrotropin releasing hormone in dairy cows fed varying amounts of iodine. J Dairy Sci 60: 975-980

DELANGE F 1993: Requirements of iodine in humans. In: DELANGE F, DUNN JT, GLINOER D (Editors): Iodine deficiency in Europe. Plenum Press N.Y. and London, pp. 5-13

DOWNER JV, HEMKEN RW, FOX JD, BULL LS 1981: Effect of dietary iodine on tissue content of the bovine. J Anim Sci 52: 413-417

HERZIG I, PÍSAŘÍKOVÁ B, KURSA J, ŘÍHA J 1999: Defined iodine intake and changes of its concentration in urine and milk of dairy cows. Vet Med-Czech 44: 35-40

KAUFMANN S, KURSA J, KROUPOVÁ V, RAMBECK W 1998a: Iodine in milk by supplementing feed: an additional strategy to erase iodine deficiency. Vet Med-Czech 43: 173-179

KAUFMANN S, WOLFRAM G, DELANGE F, RAMBECK WA 1998b: Iodine supplementation of laying hen feed: A supplementary measure to eliminate iodine deficiency in humans? Z Ernährungswiss 37: 288- 293

KURSA J, HERZIG I, TRÁVNÍČEK J, KROUPOVÁ V 2005: Milk as a food source of iodine for human consumption in the Czech Republic. Acta Vet Brno 74: 255-264

MAAS J, BERG JN, PETERSEN RG 1989: Serum distribution of iodine after oral admini-stration of ethylenediamine dihydroiodide in cattle. Am J Vet Res 50: 1758-1759

MOTULSKY HJ 1999: Analyzing data with GraphPad Prism, GraphPad Software Inc., San Diego CA; www.graphpad.com.

NĚMEČKOVÁ A et al. 1991: Medical chemistry and biochemistry (in Czech). Part 1, 1. ed. Prague, Avicenum, $661 \mathrm{p}$.

ROUBALOVÁ M 2005: Poultry and eggs. Situation and prospect report of the Ministry of Agriculture of the Czech Republic (in Czech), 36 p.

PENNINGTON JAT 1990: Iodine concentrations in US milk: variation due to time, season, and region. J Dairy Sci 73: 3421 - 3427 